2nd International Conference on Agricultural Biosystems (AGRIBIOS 2019) on 28,29 September 2019 in GBC meeting and conference room, Deira, Dubai, UAE.

\title{
Conference Chair:
}

Dr. Fattaneh Daneshmand Malayeri

Head of Research Groups, Asia Center of Energy, Environment and Ecology, UAE Main Contact: drfd54@yahoo.com

\section{Committee Members:}

Dr. Luc Hens, Editor in Chief, "Environment, Development and Sustainability", Belgium

Dr. Felisbina Luisa Queiroga, University of Trás-os-Montes and Alto Douro, Portugal

Dr. Ekaterina Arabska, University of agribusiness and rural development, Bulgaria

Dr. Waleed Fouad Abobatta, Agriculture Research Center (ARC), Egypt

Dr. Khaled Adly Khaled, Faculty of Agriculture, Beni-Suef University, Egypt

Dr. Khalid Mahrose, Animal and Poultry Dept., Zagazig University, Egypt

Dr. Zakaria Fouad Fawzy Hassan, Professor of National Research Centre, Egypt 